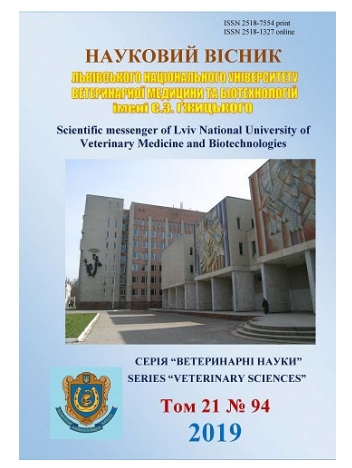

\author{
Науковий вісник Дьвівського національного університету \\ ветеринарної медицини та біотехнологій імені С.3. Гжицького. \\ Серія: Ветеринарні науки \\ Scientific Messenger of Lviv National University \\ of Veterinary Medicine and Biotechnologies. \\ Series: Veterinary sciences
}

\title{
Clinical and pathogenetic changes in dogs with chronic pancreatitis
}

\author{
A.G. Milastnaia, V.B. Dukhnitsky \\ National University of Life and Environmental Sciences of Ukraine, Kyiv, Ukraine
}

Article info

Received 30.04.2019

Received in revised form 29.05.2019

Accepted 30.05.2019

National University of Life and Environmental Sciences of Ukraine, Potehin str. 16, ed. Building 12, Kyiv, 03041, Ukraine. Tel.: +38-097-807-76-05 E-mail:a.milastnaia@gmail.com
Milastnaia, A.G., \& Dukhnitsky, V.B. (2019). Clinical and pathogenetic changes in dogs with chronic pancreatitis. Scientific Messenger of Lviv National University of Veterinary Medicine and Biotechnologies. Series: Veterinary sciences, 21(94), 174-178. doi: 10.32718/nvlvet9432

The article presents the results of chronic canine pancreatitis retrospective research based on comparison of clinical, biochemical and histopathological data. To compare the symptoms and the clinical course of chronic pancreatitis, the dogs' with clinically confirmed diagnosis history of the disease was used. The data were obtained from the private hospital of veterinary medicine (Kyiv-city) database of pathologoanatomical records, conducted at the, regarding dogs with histological confirmation chronic pancreatitis that was determined based on pancreatic tissue irreversible histological changes (fibrosis and atrophy). It was established that most often chronic pancreatitis manifests by apathy, appetite decreasing, vomiting and diarrhea. Chronic pancreatitis is more common in old decorative breed dogs that have been sterilized, with the simultaneous pathology of the endocrine, hepatobiliary and nervous systems. In sick dogs' blood serum observed high levels of enzymes that reflect the functional state of the liver and pancreas, increased bilirubin levels. At histological researches observed necrosis of pancreatic and surrounding connective tissues. The results of our research indicate that dogs' chronic pancreatitis has no clear clinical signs, however, the most common symptoms are diarrhea, abdominal pain, chronic vomiting, loss of appetite. The most common clinical and biochemical disorders were increased serum transaminases and bilirubin concentrations. The similarity of clinical signs in dogs with acute and chronic pancreatitis shows us that chronic pancreatitis may be the result of acute pancreatitis numerous attacks. For our opinion, the pathogenesis of dogs' chronic pancreatitis based on necrotic pancreas process and the replacement of normal tissues on fibroids. Probably, that in an animal with chronic pancreatitis, without the presence of pancreatic and surrounding tissue necrosis, specific clinical signs develop less frequently. In our research, we differentiated them as patients with chronic pancreatitis based on a histopathological research.

Key words: cow, lactation, age, after delivery, metritis, mastitis, latency delay, birth paresis.

\section{Клініко-патогенетичні зміни у собак, хворих на хронічний панкреатит}

\author{
А.Г. Міластная, В.Б. Духницький
}

Наџіональний університет біоресурсів і природокористування Украӥни, Київ, Україна

\footnotetext{
У статті наведено результати ретроспективного дослідження хронічного панкреатиту собак на основі співставлення клінічних, клініко-біохімічних та гістопатологічних даних. Для порівняння симптомів і клінічного перебігу хронічного панкреатиту використовували дані історій хвороби собак із клінічно підтвердженим діагнозом. Із бази даних про патологоанатомічні розтини, проведені у приватній лікарні ветеринарної медицини м. Києва, було отримано дані, ияодо собак із гістологічним підтвердженням хронічного панкреатиту, щзо було визначено на основі незворотних гістологічних змін тканин підшлункової залози, таких як фіброз і атрофія. Встановлено, що найчастіше хронічний панкреатит проявляється апатією, зниженням апетиту, блюванням і діареєю. Хронічний панкреатит частіше трапляється у старих собак, декоративних порід, які були піддані стерилізації, з одночасною патологією ендокринної, гепатобіліарної та нервової систем. У сироватці крові хворих собак виявляли високу активність ензимів, які відображають функціональний стан печінки та підшлункової залози, зростання рівня білірубіну, а гістологічними дослідженнями некроз підшлункової залози та навколишньої пухкої сполучної тканини. Результати нашого дослідження засвідчують про те, щзо хронічний панкреатит у собак не має чітких клінічних ознак, однак, найбільш розповсюдженими симптомами є діарея, абдомінальний біль, хронічне блювання, зниження апетиту. Найрозповсюдженішими клініко-біохімічними порушеннями було збільшення активності трансаміназ у сироватці крові та концентрації білірубіну. Схожість клінічних ознак у собак, хворих на гострий $i$
} 
хронічний панкреатит може слугувати додатковим підтвердженням того, щяо хронічний панкреатит, може бути результатом численних нападів гострого панкреатиту. Вважаємо, що в патогенезі хронічного панкреатиту собак важливим є розвиток некротичного прочесу та заміна нормальних тканин на фіброзну. Вірогідно, шчо у тварини із хронічним панкреатитом без наявності некрозу підшлункової залози і навколишньої клітковини рідше розвиваються характерні клінічні симптоми, однак у даному дослідженні ми диференціювали їх як хворих на хронічний панкреатит на основі гістопатологічного дослідження.

Ключові слова: підилункова залоза, панкреатит, собака, панкреанекроз.

\section{Вступ}

Хронічний панкреатит собак - захворювання з недостатньо дослідженими етіологією, патофізіологічними механізмами розвитку, клінічними проявами, а діагностика та лікування тварин за цієї патології потребують обгрунтування та удосконалення. Літературні дані щодо клінічних ознак, клініко-патогенетичних механізмів та гістопатологічних змін у собак, хворих на хронічний панкреатит є надзвичайно обмеженими (Goralsky, 2013). Нещодавно опубліковані дослідження клінічних і клініко-патогенетичних аспектів хронічного панкреатиту собак стосувались лише двох порід, інші літературні джерела базуються, в основному, на результатах розтину і гістопатологічних дослідженнях, які засвідчують про наявність хронічного панкреатиту у великої кількості тварин, однак ці дані жодним чином не екстраполюють із клінічними проявами та перебігом хронічного панкреатиту (Steiner, 2003; Newman et al., 2006; Mansfield et al., 2012). Незначна кількість публікацій та клінічний досвід показують, що хронічний панкреатит діагностується досить рідко, що засвідчує про субклінічний перебіг патології та важкість постановки діагнозу.

Через складність клінічної діагностики хронічного панкреатиту, гістопатологічне дослідження вважається найбільш надійним, однак, консенсусу відносно термінології, класифікації та диференціації різних форм панкреатиту собак на теперішній час не досягнуто (Xenoulis, 2015). В останніх літературних джерелах наведено різноманітні класифікації хронічного панкреатиту запозичені із медичної практики. Отже, клінічні дослідження собак, хворих на хронічний панкреатит надзвичайно важливі для кращого визначення і розуміння клінічних аспектів даного стану та виявлення зв'язків між клінічними проявами і гістопатологічними змінами у собак, хворих на гострий панкреатит.

Метою дослідження було встановлення та опис клінічних і клініко-патогенетичних змін у собак, хворих на хронічний панкреатит i співставлення іx iз даними розтину.

\section{Матеріал і методи досліджень}

У дослідженнях використовували історії хвороби собак, отримані із приватних клінік ветеринарної медицини м. Києва, протягом 2016-2018 років; протоколи розтину собак, отримані із бази даних кафедри патологічної анатомії Національного університету біоресурсів і природокористування України. Для досягнення мети дослідження, хронічний панкреатит діагностували виключно на основі гістопатологічних критеріїв, які включали запальну (нейтрофільну та/або лімфоцитарну) інфільтрацію підшлункової залози; незворотні зміни - атрофію підшлункової залози та фіброз; випадки із гістіоцитарним запаленням, неоплазією підшлункової залози та ознаками інфікування було виключено. Всі доступні дані із історій хвороби було проаналізовано, включаючи клініко-анамнестичні, свідчення про наявність супутніх захворювань та тривалість лікування, результати гематологічного дослідження, біохімічного аналізу сироватки крові хворих собак, ультразвукового дослідження тощо. Клінічні ознаки класифікували, як гостpi, якщо їх тривалість була менше трьох тижнів, та як хронічні, якщо більше трьох тижнів відповідно. Реєстрували тільки ті лікарські засоби, які тварини отримували під час стаціонарного лікування та за три тижні до нього. Вищезазначені клінічні випадки захворювання собак було розподілено на дві групи: тварини хворі на клінічний хронічний панкреатит (із симптомами блювання, діареї, зниження апетиту) і клінічно не діагностований хронічний панкреатит (діагноз ставили за даними розтину, гістологічного дослідження та відсутності характерних симптомів у історії хвороби).

Супутні захворювання собак із хронічним панкреатитом реєстрували і класифікували за системним принципом: хвороби ендокринної системи, нервової системи, хвороби печінки та жовчних проток, хвороби системи дихання, хвороби системи сечовиділення, серцева недостатність.

Гістологічне сортування. Кожен гістопрепарат оцінювали за наступними показниками: нейтрофільне запалення, лімфоцитарне запалення, некроз підшлункової залози, набряк, фіброз, атрофія, гіперпластичні вогнища. Кожен параметр було градуйовано за бальною системою: 0 балів - відсутність параметра, 1 бал - 10\% ураження; 2 бали - 10-50\% ураження; 3 бали $>50 \%$ ураження.

Статистичний аналіз. Описову статистику (середні значення та діапазони відхилення) було розраховано для кількісних параметрів: вік, вага, значення показників біохімічних і гематологічних досліджень. Категоріальні змінні, такі як порода, стать, лікування, супутні захворювання, клінічні ознаки розраховувались за процентним співвідношенням.

\section{Результати досліджень}

Першочергово, на основі гістопатологічних даних, отриманих під час розтину 26 собак, було діагностовано клінічний хронічний панкреатит у 19 тварин (73\%); у інших 7 тварин (26\%) патологію було класифіковано як клінічно не діагностований хронічний 
панкреатит. Досліджувані собаки представлені 7 породами, а найбільшу кількість становили метиси -8 тварин (31\%) та ретривери - 7 тварин (27\%), йоркширські тер'єри - 4 тварини (15\%), такси - 3 тварини $(11 \%)$, чіахуа - 2 тварини $(8 \%)$, бігль -1 тварина (4\%), мопс - 1 тварина (4\%).

Тварини були віком від 2,3 до 9,7 років.

Серед 26 собак вісімнадцять були суки (69\%), 3 яких 12 стерилізовані і шість статевозрілі, 8 псів (31\%) 6 кастрованих і 2 статевозрілі.

Середня вага собак, хворих на хронічний панкреатит була від 2 до 34 кг.

Клінічні ознаки і результати клінічного обстеження. Найбільш розповсюдженою клінічною ознакою була апатія - у 21 тварини (81\%), на наступному місці зниження апетиту - у 19 тварин (73\%), блювання - 16 тварин (61\%), діарея - 11 тварин (42\%). У 16 із 26 собак (61\%) блювання було хронічним з епізодичним проявом протягом більше ніж 3 тижні; 9 собак (35\%) мали ознаки абдомінального болю, а у 7 собак (27\%) була встановлена підвищена температура тіла. Клінічні прояви, супутня патологія та призначені лікарські засоби наведені у таблиці 1.

\section{Таблиця 1}

Клінічні прояви, супутня патологія та призначені лікарські засоби собакам

\begin{tabular}{|c|c|c|}
\hline & $\begin{array}{c}\text { Клінічний } \\
\text { хронічний } \\
\text { панкреатит, } \\
\text { (n = 19) }\end{array}$ & $\begin{array}{c}\text { Клінічно не } \\
\text { діагностований } \\
\text { хронічний пан- } \\
\text { креатит, }(\mathrm{n}=7)\end{array}$ \\
\hline \multicolumn{3}{|c|}{ Клінічні прояви } \\
\hline Апатія & $18(94 \%)$ & $3(43 \%)$ \\
\hline Відсутність апетиту & $17(89 \%)$ & $2(29 \%)$ \\
\hline Блювання & $16(84 \%)$ & - \\
\hline Діарея & $11(58 \%)$ & - \\
\hline Абдомінальний біль & $6(31 \%)$ & $2(29 \%)$ \\
\hline $\begin{array}{l}\text { Підвищення } \\
\text { температури тіла }\end{array}$ & $5(26 \%)$ & $2(29 \%)$ \\
\hline \multicolumn{3}{|c|}{ Супутня патологія } \\
\hline Ендокринної системи & $8(42 \%)$ & $1(14 \%)$ \\
\hline Нервової системи & $3(16 \%)$ & - \\
\hline Органів дихання & $2(11 \%)$ & - \\
\hline $\begin{array}{l}\text { Печінки та жовчних } \\
\text { проток }\end{array}$ & $7(36 \%)$ & $4(57 \%)$ \\
\hline $\begin{array}{l}\text { Хвороби системи } \\
\text { сечовиділення }\end{array}$ & $5(26 \%)$ & $3(43 \%)$ \\
\hline Серцева недостатність & $2(11 \%)$ & - \\
\hline \multicolumn{3}{|c|}{ Зазначені в історії хвороби лікарські засоби } \\
\hline Антибіотики & $14(74 \%)$ & $3(43 \%)$ \\
\hline Кортикостероїди & $7(37 \%)$ & $3(43 \%)$ \\
\hline
\end{tabular}

Як видно із даних, які наведені у таблиці 1, поширеність таких симптомів, як апатія, відсутність апетиту, блювання та діарея є більш характерним для клінічного хронічного панкреатиту, у той час як абдомінальний біль і підвищення температури встановлено в однакової кількості собак, тому на нашу думку вони не є характерними проявами хвороби.

У тварин із клінічним хронічним панкреатитом досить часто можна спостерігати супутні ендокринні захворювання (цукровий діабет, гіпоадренокортицизм тощо), друге місце за поширеністю займає патологія печінки та жовчних шляхів, однак ії частіше спостерігали за клінічно не діагностованого хронічного панкреатиту собак.

Єдиною розбіжністю за застосуванням лікарських засобів собакам хворим на клінічний і клінічно не діагностований панкреатит було те, що тваринам, хворим на клінічний хронічний панкреатит частіше призначали антибіотики.

Результати біохімічного аналізу сироватки крові собак із клінічним і клінічно не діагностованим хронічним панкреатитом та результати гематологічного дослідження наведені у таблицях 2 і 3 відповідно.

\section{Таблиця 2}

Показники біохімічного аналізу сироватки крові собак

\begin{tabular}{|c|c|c|c|}
\hline Показники & $\begin{array}{c}\text { Рефе- } \\
\text { ренсні } \\
\text { значення }\end{array}$ & $\begin{array}{c}\text { Клінічний } \\
\text { хронічний } \\
\text { панкреатит, } \\
(\mathrm{n}=19) \\
\end{array}$ & $\begin{array}{c}\text { Клінічно не } \\
\text { діагностований } \\
\text { хронічний пан- } \\
\text { креатит, }(\mathrm{n}=7)\end{array}$ \\
\hline $\begin{array}{l}\text { Білірубін, } \\
\text { мкмоль/л }\end{array}$ & $0,1-15$ & $21,6 \pm 4,7$ & $12,8 \pm 5,2$ \\
\hline $\begin{array}{l}\text { Аланінамінот- } \\
\text { рансфераза, } \\
\text { Од/л }\end{array}$ & $9-42$ & $56,3 \pm 7,9$ & $38,7 \pm 5,5$ \\
\hline $\begin{array}{l}\gamma \text {-глутаміл- } \\
\text { транспептидаза, } \\
\text { Од/л }\end{array}$ & $1-6$ & $12,5 \pm 1,2$ & $8,3 \pm 0,8$ \\
\hline $\begin{array}{l}\text { Лужна фосфа- } \\
\text { таза, Од/л }\end{array}$ & $50-90$ & $146,5 \pm 12,4$ & $112,7 \pm 5,9$ \\
\hline $\begin{array}{l}\text { Сечовина, } \\
\text { ммоль/л }\end{array}$ & $2,0-8,3$ & $7,3 \pm 0,8$ & $8,1 \pm 1,1$ \\
\hline $\begin{array}{l}\text { Креатинін, } \\
\text { мкмоль/л }\end{array}$ & $26-120$ & $109,6 \pm 8,8$ & $102,4 \pm 6,1$ \\
\hline
\end{tabular}

Як видно із даних, що наведені у таблиці 2, у сироватці крові собак, хворих на клінічний хронічний панкреатит, була значно більшою концентрація білірубіну та вища активність аланінамінотрансферази, лужної фосфатази і $\gamma$-глутамілтранспептидази, ніж у собак із клінічно не діагностованим захворюванням. Активність специфічної панкреатичної ліпази було досліджено у 11 собак хворих на клінічний хронічний панкреатит. Перевищення іiі контрольного діапазону було встановлено у 6 тварин.

Дані, які наведені у таблиці 3, показують що у крові собак хворих на клінічний хронічний панкреатит збільшується кількість лейкоцитів на 9\%, порівняно із верхнім референсним значенням, зокрема їх кількість була на $11 \%$ більшою, ніж у тварин із клінічно не діагностованим хронічним панкреатитом. Показники лейкограми не виходили за межі референсних значень.

Гістологічним дослідженням зрізів підшлункової залози собак виявили фіброз, некроз підшлункової залози, перипанкреатичний набряк, нейтрофільне та лімфоцитарне запалення, атрофію і гіперпластичні вузли. 
Таблиця 3

Морфологічні показники крові собак

\begin{tabular}{lccc}
\hline \multicolumn{1}{c}{ Показники } & $\begin{array}{c}\text { Референсні } \\
\text { значення }\end{array}$ & $\begin{array}{c}\text { Клінічний } \\
\text { хронічний панкреатит, }(\mathrm{n}=19)\end{array}$ & $\begin{array}{c}\text { Клінічно не діагностований } \\
\text { хронічний панкреатит, }(\mathrm{n}=7)\end{array}$ \\
\hline Еритроцити, Т/л & $5,4-7,8$ & $6,1 \pm 0,43$ & $5,9 \pm 0,58$ \\
Лейкоцити, Г/л & $7,0-12,0$ & $13,1 \pm 1,26$ & $11,8 \pm 1,87$ \\
Базофіли, \% & $0-1$ & 0 & 0 \\
Еозинофіли, \% & $2-10$ & $4,1 \pm 0,7$ & $5,2 \pm 0,9$ \\
Паличкоядерні нейтрофіли, \% & $1-6$ & $5,8 \pm 0,8$ & $5,1 \pm 1,1$ \\
Сегментоядерні нейтрофіли, \% & $50-72$ & $67,3 \pm 2,9$ & $65,7 \pm 3,1$ \\
Лімфоцити, \% & $18-30$ & $19,6 \pm 1,6$ & $20,4 \pm 1,8$ \\
Моноцити, \% & $0-6$ & $3,2 \pm 0,4$ & $3,6 \pm 0,2$ \\
\hline
\end{tabular}

У тварин із клінічним хронічним панкреатитом частіше виявляли некроз перипанкреатичної клітковини і панкреанекроз, ніж у тварин із клінічно не діагностованим хронічним панкреатитом.

Результати ультразвукового дослідження черевної порожнини показали збільшення розмірів підшлункової залози у 18 собак, дрібні гіперехогенні включення (кальцифікати) у 11 собак, набряк підшлункової залози у 4 тварин, однак у 2 тварин ультразвуковим дослідженням не вдалося візуалізувати підшлункову залозу, але у них спостерігали ознаки вираженого абдомінального болю.

\section{Обговорення}

Одним із найбільш важливих результатів даного дослідження є встановлення у значної кількості тварин хворих на клінічний хронічний панкреатит значно більшої кількості випадків щодо некрозу підшлункової залози і перипанкреатичної клітковини (більша кількість балів), ніж у тварин із клінічно не діагностованим панкреатитом. Некроз підшлункової залози та перипанкреатичної клітковини найчастіше пов'язують iз гострим панкреатитом і вважають їх свідченням того, що у багатьох собак, хворих на клінічний хронічний панкреатит також був гострий панкреатит. Активна фаза захворювання підшлункової залози (за наявності некротичних ділянок самої залози і перипанкреатичної клітковини) у тварин із симптомами клінічного хронічного панкреатиту засвідчує вищу розповсюдженість клінічних ознак у собак даної групи порівняно із тваринами хворими на клінічно не діагностований панкреатит. Це пояснює розходження в оцінюванні розповсюдженості даного захворювання за результатами гістологічного дослідження патологічного матеріалу і клінічною картиною. Вірогідно, що у тварин із хронічним панкреатитом без наявності некрозу підшлункової залози і навколишньої клітковини рідше розвиваються характерні клінічні симптоми, однак у даному дослідженні ми диференціювали їх як хворих на хронічний панкреатит на основі гістопатологічного дослідження. Вважаємо, що в патогенезі хронічного панкреатиту собак важливим $є$ розвиток некротичного процесу та заміна нормальних тканин на фіброзну. Дана теорія пояснюється тим, що незворотні зміни у підшлунковій залозі можуть бути спричинені повторними випадками гострого панкреатиту.
Таке припущення підтверджується схожістю клінічних симптомів у собак хворих на гострий панкреатит, i собак із хронічним запальним процесом у підшлунковій залозі. Результати нашого дослідження засвідчують про те, що хронічний панкреатит у собак має нечіткі клінічні ознаки, однак, найбільш розповсюдженими клінічними симптомами є діарея, абдомінальний біль, хронічне блювання, зниження апетиту. Найрозповсюдженішими клініко-біохімічними порушеннями було підвищення активності трансаміназ у сироватці крові та збільшення концентрації білірубіну. Схожість клінічних ознак у собак, хворих на гострий i хронічний панкреатит $є$ додатковим підтвердженням того, що хронічний панкреатит може бути результатом численних нападів гострого панкреатиту.

\section{Висновки}

1. Хронічний панкреатит у собак не має специфічних клінічних ознак, а найбільш розповсюдженими симптомами $є$ діарея, абдомінальний біль, хронічне блювання, зниження апетиту.

2. Основними клініко-біохімічними порушеннями у собак, хворих на хронічний панкреатит є підвищення активності трансаміназ у сироватці крові та збільшення концентрації білірубіну.

3. У патогенезі хронічного панкреатиту собак важливе значення має розвиток некрозу і фіброзу тканин підшлункової залози та перипанкреатичної клітковини.

Перспективи подальших досліджень передбачають встановлення етіологічних чинників і патогенетичних механізмів розвитку панкреатиту у собак.

\section{References}

Goralsky, L.P., Timoshenko, O.P., \& Borisevich, B.V. (2013). Pankreatit sobak. Polissya, Zhitomir (in Ukrainian).

Mansfield, C.S., Anderson, G.A., \& O'Hara, A.J. (2012). Association between canine pancreatic-specific lipase and histologic exocrine pancreatic inflammation in dogs: assessing specificity. J Vet Diagn Invest., 24(2), 312-318. doi: 10.1177/1040638711433598.

Newman, S.J., Steiner, J.M., Woosley, K., Williams, D.A., \& Barton, L. (2006). Histologic assessment and grading of the exocrine pancreas in the dog. $\mathrm{J}$ Vet 
Diagn Invest., 18(1), 115-118. doi: Xenoulis, P.G. (2015) Diagnosis of pancreatitis in dogs $10.1177 / 104063870601800119$.

Steiner, J.M. (2003). Diagnosis of pancreatitis. Vet Clin and cats. J Small Anim Pract., 56(1), 13-26. North Am Small Anim Pract., 33, 1181-1195. doi: $10.1111 /$ jsap. 12274 . doi: 10.1016/S0195-5616(03)00061-5. 